\title{
Effects of manganese oxide-modified biochar composites on arsenic speciation and accumulation in an indica rice (Oryza sativa L.) cultivar
}

\author{
Zhihong Yu ${ }^{\mathrm{a}}$, Weiwen Qiu ${ }^{\mathrm{b}}$, Fei Wang ${ }^{\mathrm{a}}$, Ming Lei ${ }^{\mathrm{c}}$, Di Wang ${ }^{\mathrm{a}}$, Zhengguo Song ${ }^{\mathrm{a}^{*}}$ \\ a Agro-environmental protection institute, Ministry of Agriculture, Key Laboratory of \\ Production Environment Quality, Ministry of Agriculture of China, Tianjin 300191, China \\ b The New Zealand Institute for Plant and Food Research Limited, Private Bag 4704, \\ Christchurch 8140, New Zealand \\ c College of Resource and Environment, Hunan Agricultural University, Changsha 410128, \\ China
}

Corresponding Author: Prof. Zhengguo Song

Email: forestman1218@163.com

\begin{abstract}
A pot experiment was used to investigate arsenic (As) speciation and accumulation in rice, as well as its concentration in both heavily contaminated and moderately contaminated soils amended with manganese oxide-modified biochar composites (MBC) and biochar alone (BC). In heavily As-contaminated soil, application of BC and MBC improved the weight of above-ground part and rice root, whereas in moderately As-contaminated soil, the application of $\mathrm{MBC}$ and low rate $\mathrm{BC}$ amendment increased rice root, grain weight and the biomass of the plant. Arsenic reduction in different parts of rice grown in $\mathrm{MBC}$-amended soils was greater than that in plants cultivated in BC-amended soils. Such reduction can be attributed to the oxidation of arsenite, As(III), to arsenate, As(V), by Mn-oxides, which also had a strong adsorptive capacity for As(V). MBC amended to As-contaminated soil had a positive effect on amino acids. The $\mathrm{Fe}$ and $\mathrm{Mn}$ levels in the iron-manganese plaque that formed on the rice root surface differed among the treatments. MBC addition significantly increased Mn content ( $p<0.05$ ); the application of 2.0\% MBC increased Mn content 36- and 10-fold compared to the control in heavily and moderately As-contaminated soils, respectively. The results indicate that application of Mn oxide-modified biochar to As-contaminated paddy soil could effectively remediate contaminated soil and reduce As accumulation in edible parts of rice.
\end{abstract}

Keywords: arsenic, manganese oxide-biochar composites, paddy soil, brown rice

Capsule: Manganese oxide-modified biochar effectively remediates arsenic-contaminated soils and reduces arsenic accumulation in edible parts of rice.

\section{Introduction}


Arsenic (As) is a ubiquitous metalloid found in the environment that is potentially toxic to living organisms. It is derived from both natural and anthropogenic sources. Anthropogenic activities, such as mining, smelting, pesticide application, or irrigation with contaminated groundwater, can create additional As contamination in the soils (Naidu et al., 2006; Smith et al., 1998). Arsenic released into soil and aquifers is in both inorganic and organic forms. Generally inorganic As species are considered to be more mobile and more toxic than organic forms (Meharg and Jeanette Hartley, 2002). The toxicity and bioavailability of soil As are determined by soil properties, notably mineral composition, organic matter content, $\mathrm{pH}$, redox potential, and phosphate content ( $\mathrm{Cao}$ and $\mathrm{Ma}, 2004$; Warren et al., 2003). Arsenate, As(V), is the predominant species in aerobic soils, whereas arsenite, As(III), dominates under anaerobic conditions such as paddy soil (Smith et al., 1998). Arsenite is the most predominant species, followed by dimethylarsinic acid (DMAA), $\mathrm{As}(\mathrm{V})$, and monomethylarsonic acid (MMAA) that accumulate around rice rhizosphere in As-contaminated, flooded paddy fields (Abedin et al., 2002). Apart from the health risks directly associated with the consumption of As-contaminated drinking water, the transfer and translocation of As in soil-plant systems are thought to be a major pathway for human As exposure, causing adverse effects on human health (Leupin et al., 2005; Zhu et al., 2008).

Rice (Oryza sativa L.) is the dominant staple food in many parts of the world, particularly in Southeast Asia and South China, contributing to most of the daily caloric intake per capita (Neidhardt et al., 2012; Norton et al., 2009). Rice is particularly efficient in As accumulation compared to other cereals, as it is generally grown under flooding-reduced conditions, where As bioavailability is increased (Heikens, 2006). Baseline levels of As in rice are 10-fold higher than those in other cereal grains (Williams et al., 2007). The As concentration in the edible parts of crops depends on the availability of soil As and the ability of crops to uptake As and transfer/translocate it to the target organs (Rosas-Castor et al., 2014). In general, plants can tolerate up to $2 \mathrm{mg} \mathrm{kg}^{-1}$ of As in soil (Kabata-Pendias and Mukherjee, 2007). Higher concentrations of As are toxic to crops and can cause necrosis, inhibit growth, and ultimately lead to plant death (Gulz et al., 2005). Thus, methods of decreasing the uptake of As by rice from soil and the content of As in rice grains can be effective strategies to reduce the threat posed by As to human health.

There are several methods that can regulate the transfer of As from soil to rice grains, such as soil replacement, chemical immobilization, electrokinetics, soil flushing, vitrification, and phytoremediation (Balasubramanian et al., 2009; Komárek et al., 2013; Marques et al., 2009; Mench et al., 2003). Chemical immobilisation techniques in particular have been recommended in the remediation of As-contaminated soils because they are cost-effective, relatively safe, and less disruptive to soils. Many chemical absorbents, such as carbonaceous materials, clay minerals, iron compounds, aluminium oxides, manganese oxides, have been proposed to treat As-contaminated soils (Kumpiene et al., 2008). In recent years, some 
researchers have used carbon-based stabilising materials for the remediation of Ascontaminated soils (Hassan et al., 2014). Biochar is a pyrogenic carbon material produced by the combustion of biomass under oxygen-limited conditions. Biochar can be used for soil improvement, fertility enhancement, and carbon sequestration due to its unique properties such as high surface area and cation exchange capacity (Mohan et al., 2014; Zimmerman et al., 2011). It has also shown great potential in the retention of several heavy metals and in the control of contaminants in soils (Ahmad et al., 2014). However, the surfaces of most of the biochars are predominantly net negatively charged, and As in the environment mainly exists in the form of oxyanions, which limits the As adsorption capacity of biochar. Moreover, biochar may raise soil $\mathrm{pH}$, which could increase the mobility of As and cause plants to take up As more readily. With regard to these specific challenges when biochar is utilized for reclamation of As, the impregnation of biochar with Mn oxides to assist the immobilization of As in soils may be a better option, as Mn oxides can limit As mobility via anion exchange and can convert $\mathrm{As}(\mathrm{III})$ to a less toxic $\mathrm{As}(\mathrm{V})$ in soils because of its high oxidation potential (Lafferty et al., 2010; Yu et al., 2015).

Given that manganese oxide and manganese oxide-modified materials show strong ability to immobilise As and have high oxidation potential, they can be used as potential costeffective adsorbents for the remediation of As in soils (Gregory et al., 2014; Namgay et al., 2010; Yu et al., 2015). To date, few studies have evaluated the effects of manganese oxidemodified biochar composites (MBC) on the reduction of As bioavailability in paddy soil. Further studies are required to elucidate the influence of $\mathrm{MBC}$ on soil chemistry and biology when applied to As-contaminated soil in the presence of rice cultivars. Therefore, the objectives of this study were to (i) investigate the effects of $\mathrm{MBC}$ and biochar on As speciation and concentration in rice and the amino acid content in rice grain grown in two Ascontaminated paddy soils, (ii) determine how MBC regulate soil As availability, and (iii) discuss the possible influence mechanism on soil As bioavailability.

\section{Material and methods}

\subsection{Chemicals and reagents}

All chemicals, including sodium hydroxide $(\mathrm{NaOH})$, sodium nitrate $\left(\mathrm{NaNO}_{3}\right)$, disodium phosphate $\left(\mathrm{Na}_{2} \mathrm{HPO}_{4}\right)$, monopotassium phosphate $\left(\mathrm{KH}_{2} \mathrm{PO}_{4}\right)$, hydrochloric acid $(\mathrm{HCl})$, and potassium permanganate $\left(\mathrm{KMnO}_{4}\right)$ used in this study, with the exception of arsenic trioxide $\left(\mathrm{As}_{2} \mathrm{O}_{3}, 99.99 \%\right.$, AnalaR reagent, BDH, Poole, England), were purchased from Guangfu Corporation (China) and were of analytical grade. The standard As(III) stock solution was prepared by dissolving $\mathrm{NaAs}_{2} \mathrm{O}_{3}$ in $\mathrm{NaOH}$ and standards of arsenate $\mathrm{As}(\mathrm{V})$, dimethylarsinate(DMAA) and monomethylarsonate(MMAA) were purchased from Sigma-Aldrich 
(U.S.A) and then diluting the solution with deionized (DI) water (resistance $18.2 \mathrm{M} \Omega \mathrm{cm}$ ) in a polyethylene plastic bottle.

\subsection{Physicochemical properties of soil}

Samples from upper horizon $(0-20 \mathrm{~cm})$ of two As-contaminated paddy soils were used and collected from a heavily As-contaminated field and moderately As-contaminated field in Chenzhou County, Hunan Province, China. Both soils were air-dried and sieved through a 3$\mathrm{mm}$ sieve before used. The properties of each soil are shown in Table 1.

\subsection{Preparation of manganese oxide-modified biochar composites}

The synthesis of biochar was described previously (Yu et al., 2015). Briefly, biochar was produced from corn straw by slow pyrolysis at $600{ }^{\circ} \mathrm{C}$ for $2 \mathrm{~h}$ in a muffle furnace under nitrogen gas $\left(\mathrm{N}_{2}\right)$ atmosphere (flow rate $300 \mathrm{~mL} \mathrm{~min}^{-1}$ ). Subsequently, $5.0 \mathrm{~g}$ biochar was soaked with $40 \mathrm{~mL}$ of $\mathrm{KMnO}_{4}(0.079 \mathrm{M})$ solution and subjected to pyrolysis at $600{ }^{\circ} \mathrm{C}$ for another $0.5 \mathrm{~h}$ to create $\mathrm{MBC}$. The weight ratio of biochar to $\mathrm{KMnO}_{4}$ was $10: 1$. The resulting samples were rinsed, thoroughly rewashed using deionized (DI) water to remove any impurities, and dried at $80^{\circ} \mathrm{C}$. Untreated biochar (BC) was also included in the experiment for comparison. The properties of biochars are presented in Table 2. Carbon, hydrogen, and nitrogen contents of $\mathrm{BC}$ and $\mathrm{MBC}$ were determined using an elemental analyser (Elementar Analysensysteme $\mathrm{GmbH}$, Hanau, Germany). Manganese (Mn) content in the biochar was determined using atomic adsorption spectrometry (Zeenit 700, Analytik Jena AG, Jena, Germany) after dissolution by oxalic and sulphuric acids. $\mathrm{pH}$ was measured in a 1:10 (w/w) biochar: water suspension after 1 min of shaking the mixture and then allowing it to stand for $30 \mathrm{~min}$ at $25{ }^{\circ} \mathrm{C}$. Ash contents of $\mathrm{BC}$ and $\mathrm{MBC}$ were defined as the mass remaining after heating the mixtures in an open crucible at $750{ }^{\circ} \mathrm{C}$ until a constant weight was obtained. Volatile matter was determined as the weight loss after heating the char in a covered crucible to $950{ }^{\circ} \mathrm{C}$ and maintaining that temperature for $7 \mathrm{~min}$ (Uchimiya et al., 2011). The specific surface area of $\mathrm{MBC}$ and $\mathrm{BC}$ was measured with nitrogen adsorption at $77 \mathrm{~K}$ using an Autosorb-1 gas analyser (Quantachrome Instruments, Boynton Beach, USA) and calculated by the Brunauer-Emmett-Teller method.

\subsection{Pot experiment}

The pot experiment was set up in a greenhouse starting in May 2014. Two Ascontaminated paddy soils were used in this study, i.e. heavily As-contaminated soil and moderately As-contaminated soil. After homogeneously mixing the soils, $2.5 \mathrm{~kg}$ soil was 
placed in each pot with a height of $22 \mathrm{~cm}$ and a diameter of $15 \mathrm{~cm}$. The soil was amended with $\mathrm{MBC}$ and $\mathrm{BC}$ at rates of $0.5 \%, 1 \%$, and $2 \%$ of soil weight, i.e. $12.5 \mathrm{~g}, 25 \mathrm{~g}, 50 \mathrm{~g} \mathrm{BC}$ or MBC was added to each pot respectively. Each soil had seven treatments: control (no biochar amended), soil amended with $0.5 \% \mathrm{MBC}$ or $\mathrm{BC}$, soil amended with $1 \% \mathrm{MBC}$ or $\mathrm{BC}$, and soil amended with $2 \% \mathrm{MBC}$ or $\mathrm{BC}$. The treatments were triplicated in a completely randomized factorial design. Each pot was then saturated with distilled water and drained down to an equilibrium state for $72 \mathrm{~h}$ under natural conditions. $\mathrm{KH}_{2} \mathrm{PO}_{4}, \mathrm{NH}_{4} \mathrm{NO}_{3}$, and $\mathrm{Na}_{2} \mathrm{HPO}_{4}$ were

added to each treatment as basal fertilizers at application rates of $0.2,0.1$, and $0.2 \mathrm{~g} \mathrm{~kg}^{-1}$ soil for N, P, and K supply, respectively.

Rice seeds (O. sativa xiangzaoxian-24) were germinated in seedling trays until the 3-leaf stage and then transplanted into pots. During the growth period, all pots were irrigated with distilled water daily to maintain water level of $1 \mathrm{~cm}$ above the soil surface for the first $20 \mathrm{~d}$ and $3 \mathrm{~cm}$ above the soil for the remaining days of the experiment. Rice was harvested at day 100 .

\subsection{Arsenic concentrations and species and amino acid content in rice samples}

Because As is a volatile element, very careful sample preparation, particularly for solid samples, is necessary to avoid altering its chemical composition during the extraction process (Dos Santos Costa et al., 2015). Accordingly, the following procedures were used.

After rice was harvested, the plants were washed thoroughly with DI water. All samples were dried at $80{ }^{\circ} \mathrm{C}$ and then stored at $65{ }^{\circ} \mathrm{C}$ until analysis. Each plant was separated into roots, stem, leaves, and brown rice (grain), and dry weight of each part was recorded. Dried each part of plants was ground and put into plastic bags for storage. Roots $(0.1 \mathrm{~g})$, stem and leaves $(0.2 \mathrm{~g}$ each) of each plant were digested with a solution of $1.0 \mathrm{M}$ phosphoric acid and $0.1 \mathrm{M}$ ascorbic acid in tubes for $2 \mathrm{~h}$ at $135{ }^{\circ} \mathrm{C}$ in a graphite digestion instrument (DibiBlock ED54, Lab Tech Inc., Hopkinton, MA, USA) (Lou et al., 2014). After the samples cooled down to room temperature, remaining liquids were filtered through a $0.45-\mu \mathrm{m}$ membrane filter into $25-\mathrm{mL}$ vials. The total concentration of As in each part was determined using atomic fluorescence spectroscopy (AFS 9760, Beijing Kechuang Haiguang Instrument Company, Beijing, China). To ensure the accuracy, reliability, and reproducibility of the results, all tests were conducted in triplicate. Standard samples of total As were run with every 10 samples. The percentage of recovery was $96 \%$ to $101.5 \%$, and the relative standard deviations of the results were less than $3.2 \%$.

The procedures used for As species extraction from brown rice followed those outlined by Zhu et al. (2008). Each brown rice sample $(0.5 \mathrm{~g})$ was accurately weighed in a digestion vessel after air-drying and husking to $0.3 \mathrm{~mm}$. Subsequently, $8 \mathrm{~mL}$ of $\mathrm{HNO}_{3}(1 \%)$ was added to each sample that was then incubated overnight. The samples were digested at $120{ }^{\circ} \mathrm{C}$ for 4 
$\mathrm{h}$ and cooled to room temperature. The liquids were filtered through Whatman filter paper grade 42, and $10 \mathrm{~mL}$ filtrate of each samples was analysed using AFS after additional filtering through a $0.45-\mu \mathrm{m}$ membrane filter. As(III), As(V), DMAA and MMAA were determined using HPLC (Agilent 5680)-AFS coupled with a hollow double-cathode arsenic lamp. To ensure the accuracy, reliability, and reproducibility of the results, all tests were conducted in triplicate. Mixed standard samples (As(III), As(V), DMAA and MMAA) were run with every 10 samples. The percentage of recovery was $94.5 \%$ to $109.5 \%$, and the relative standard deviations of the results were less than $4.6 \%$.

Amino acids in brown rice were measured as a percentage of rice samples after hydrolysis in 6 M HCL using a Hitachi 835-50 amino acid auto-analyser (Hitachi Co., Tokyo, Japan)

\subsection{Extraction of soil arsenic and iron-manganese plaque from roots}

The soil samples were collected after rice was harvested. Samples were air-dried and sieved through $0.3 \mathrm{~mm}$ mesh. For arsenic speciation, the soil samples were extracted and analyzed according to the methods of Yuan et al. (2007). $1 \mathrm{~g}$ of material was placed into a PTFE tubes tube and $20 \mathrm{~mL}$ extract reagent $(0.5 \mathrm{M}$ phosphate buffer $)$ was filled in the tube. The PTFE tubes were capped and placed into the microwave system (Mars5, CEM Corporation, USA) for extraction. After extraction program, the supernatant was removed after centrifuged at $3500 \mathrm{rpm}$ for $10 \mathrm{~min}$. The liquids were filtered through Whatman filter paper grade 42. As(III) and As(V) were determined using HPLC (Agilent 5680)-AFS coupled with a hollow double-cathode arsenic lamp. To ensure the accuracy, reliability, and reproducibility of the results, all tests were conducted in triplicate. Mixed standard samples $(\mathrm{As}(\mathrm{III})$ and $\mathrm{As}(\mathrm{V}))$ were run with every 10 samples. The percentage of recovery was $96 \%$ to $106 \%$, and the relative standard deviations of the results were less than $3.7 \%$.

The iron-manganese plaque that formed on fresh root surfaces was extracted using the methods described by Taylor and Crowder (1983) and Otte et al. (1991) with dithionitecitrate-bicarbonate (DCB) solution containing $0.03 \mathrm{M}$ sodium citrate $\left(\mathrm{Na}_{3} \mathrm{C}_{6} \mathrm{H}_{5} \mathrm{O}_{7} \cdot 2 \mathrm{H}_{2} \mathrm{O}\right)$, $0.125 \mathrm{M}$ sodium bicarbonate $\left(\mathrm{NaHCO}_{3}\right)$, and $0.6 \mathrm{~g}$ sodium dithionite $\left(\mathrm{Na}_{2} \mathrm{~S}_{2} \mathrm{O}_{4}\right)$. The whole root system of each plant was immersed in $200 \mathrm{~mL}$ of DCB solution for $60 \mathrm{~min}$ at room temperature. Roots were rinsed three times with deionised water added to the DCB extracts. The volume of the resulting solutions was brought to $500 \mathrm{~mL}$ with DI water. After DCB extraction, the iron-manganese plaque content was determined using hydride generationatomic fluorescence spectroscopy (AFS 9760, Beijing Kechuang Haiguang Instrument Company, China) within $24 \mathrm{~h}$.

\subsection{Statistical analysis}


All statistical analyses were performed with SPSS 21.0 software (SPSS Inc., Chicago, IL, USA). Analysis of variance was used to determine significant differences between the treatments, with $p<0.05$ indicating statistical significance.

\section{Results and discussion}

\subsection{Soils, $B C$ and $M B C$ amendments}

The heavily As-contaminated soil contained $73 \mathrm{mg} \mathrm{kg}^{-1}$ As compared to $47 \mathrm{mg} \mathrm{kg}^{-1}$ As in the moderately As-contaminated soil (Table 1). The two soils had similar $\mathrm{pH}$, organic matter and clay content; however, heavily As-contaminated soil had higher level of available P (Table 1)..

Chemical and physical properties of both $\mathrm{BC}$ and $\mathrm{MBC}$ are well known to vary according to the production process; in this case, both amendments had similar high total carbon content and $\mathrm{pH}$, but $\mathrm{MBC}$ had higher ash content and smaller specific surface than $\mathrm{BC}$, and MBC contained $7.41 \% \mathrm{Mn}$, whereas BC did not have detectable Mn (Table 2).

\subsection{Rice biomass}

Amendment with $\mathrm{MBC}$ and $\mathrm{BC}$ significantly increased rice biomass in both heavily Ascontaminated and moderately As-contaminated soils (Table 3). Compared to the control, soil amended with $\mathrm{BC}$ increased grain weight from 8.4 to $12.9 \mathrm{~g}$ per pot and soil amended with MBC increased the grain weight from 8.4 to $15.7 \mathrm{~g}$ per pot in heavily As-contaminated soil. In moderately As-contaminated soil, the grain weight increased by $9.3 \%, 18.5 \%$, and $18.1 \%$ in treatments with $1 \% \mathrm{BC}, 0.5 \%$ and $1 \% \mathrm{MBC}$ amendment respectively, relative to the control. Stem and leaf weight of most treatments in heavily As-contaminated soil were 2.3 $45.6 \%$ and $22.9-70.5 \%$ higher than the control, whereas there was only $3.8-21 \%$ and $0.6-$ $10.5 \%$ increase for stem and leaf weight in moderately As-contaminated soil, respectively. The root dry weight of the control (2.65 g per pot) was nearly $30 \%$ lower than that those treatments with addition of $2 \% \mathrm{BC}$ and $2 \% \mathrm{MBC}(p<0.05)$ in heavily As-contaminated soil. The great increase of root weight was found in $0.5 \% \mathrm{BC}$ treatment and $2 \% \mathrm{MBC}$ treatment $(\sim 16 \%)$ in moderately As-contaminated soil. In addition, biomass, leaf and grain weight in each $\mathrm{BC}$ or $\mathrm{MBC}$ treatment in heavily As-contaminated soil was lower than the respective plant parts in moderately As-contaminated soil. It has been reported that amendment of biochar to soil can augment plant growth and crop yield due to its characteristics of improving soil physical properties such as water holding capacity and aeration, increasing soil $\mathrm{pH}$, cation exchange capacity and further enhancing nutrients retention (Beesley et al., 
2011; Hartley et al., 2009; Novak et al., 2009). In this study, improvements of soil physical properties by amendment of $\mathrm{BC}$ or $\mathrm{MBC}$ can mostly be included as the reason for the increase of root weight, grain weight and biomass because $\mathrm{BC}$ or $\mathrm{MBC}$ amendment reduced the topsoil bulk density and thus also reduced resistance to root growth into the soil substrate. As a result, the development of roots would certainly strengthen the nutrient bioavailability of rice in soils, further leading the grain weight and biomass increase. On the other hand, improved soil chemical properties (e.g. $\mathrm{pH}$, cation exchange capacity (CEC)) can also reduce the toxicity of As present in rice and eliminate the growth inhibition when nutrients were not the primary limiting factor. However, increased root, rice grain, and biomass growth was not concomitant with the increase of added MBC rates, suggesting that excessive biochar addition may not lead to higher biomass and that the biochar rate should be controlled at an optimal level.

\subsection{Concentration and species of arsenic in rice plant parts}

As concentrations in rice plants for all treatments were the highest in the roots (ranging from 123 to $356 \mathrm{mg} \mathrm{kg}^{-1}$, the average $216 \pm 72 \mathrm{mg} \mathrm{kg}^{-1}$ ) in heavily As-contaminated soil and the lowest in the grain (ranging from 0.278 to $0.338 \mathrm{mg} \mathrm{kg}^{-1}$, the average $0.308 \pm 0.021 \mathrm{mg}$ $\mathrm{kg}^{-1}$ ) in moderately As-contaminated soil (Table 4). The As concentration observed in various rice tissues was within the range reported by Abedin et al. (2002) who irrigated paddy rice with various concentrations of As-contaminated water under greenhouse conditions. In the present study, As concentration in rice tissue increased in the order grain $<$ stem $\approx$ leaf $<$ root in both heavily and moderately As-contaminated soils. The increased accumulation of As in plant root tissue has been reported in some rice studies (Marin et al., 1992). As concentrations in grain, stem, leaf, and root of rice plants in heavily As-contaminated soil were higher compared to those rice plants growing in moderately As-contaminated soil. Application of MBC to both contaminated soils decreased As concentration in roots, leaves, and grain compared to the control (Table 4). The greatest effect appeared in rice plants grown in the amendment with $2 \% \mathrm{MBC}$ in heavily As-contaminated soil. In this treatment, As concentration in roots, leaves, and grain decreased by $65.4 \%, 44.8 \%$, and $19.8 \%$ respectively, compared to the control. In moderately As-contaminated soil, the most prominent reduction of As in roots, leaves, stems, and grain was observed in $1.0 \% \mathrm{MBC}$ treatment, showing $40.8 \%, 44.3 \%, 33.2 \%$, and $17.7 \%$ decrease in As concentration respectively, relative to the control. The results indicated that the As reduction by high rate $\mathrm{MBC}$ treatment was greater than that of BC treatment. As(III) was the most prominent arsenic species in different parts of rice for both types of As-contaminated soils, which contributed approximately $80 \%$ of arsenic in brown rice and more than 50\% in leaves and stems (Fig. 1 and Fig. 2), followed by As(V) and organic arsenic, including DMAA and MMAA. It can be speculated that the 
accumulation of As in edible parts of rice is mainly dependent on elemental availability in the soil as influenced by root interaction. In paddy soil, As(III) and As(V) co-exist in the soil solution and $\mathrm{As}(\mathrm{III})$ is dominated under anaerobic condition. The rice plants in all treatments, when grown in anaerobic soils, released oxygen to their rhizosphere through aerenchyma, resulting in the oxidation of ferrous iron and the formation of iron plaques, which mainly consisted of ferrihydrite on the root surface. The Fe oxides formed around roots have a strong affinity for $\mathrm{As}(\mathrm{V})$ and became a major barrier to uptake of $\mathrm{As}(\mathrm{V})$ by rice plant. Some studies using X-ray absorption spectrometry have shown that most (70 - 80\%) of As adsorbed by iron plaques on the roots of rice was $\mathrm{As}(\mathrm{V})$, with the remaining (20 - 30\%) being As(III) (Hansel et al., 2002; Liu et al., 2005). Our finding confirmed that the presence of iron plaques and Mn-oxides in MBC reduced As(V) uptake, leading to As(III) being predominant form of As in most parts of the rice plants.

\subsection{Amino acids in brown rice}

Amino acids are the main components of rice protein, and some nutritionally essential amino acids are required in human diet. Their deficiency can cause an imbalance of nitrogen equilibrium, retarded growth, malnutrition, infertility, and short life span in humans (Giordano and Castellino, 1997). In the present study, the levels of essential amino acids, nonessential amino acids, and total amino acids measured in brown rice in soils contaminated with different levels of As are shown in Table 5. The levels of both essential amino acids and nonessential amino acids were not significantly influenced by the $\mathrm{BC}$ and $\mathrm{MBC}$ treatments $(p>0.05)$. However, the ratio of essential amino acids to total amino acids in brown rice increased with the addition rate of $\mathrm{MBC}$ and $\mathrm{BC}$. Compared to the control treatment, addition of $0.5 \%, 1.0 \%$, and $2.0 \% \mathrm{MBC}$ increased the ratio of essential amino acids to total amino acids by $0.88 \%, 1.76 \%$, and $1.76 \%$ respectively, in heavily contaminated soils and by $5.5 \%$, $4.3 \%$, and $9.0 \%$ respectively, in moderately-contaminated soils. Although the level of both essential and nonessential amino acids were not significantly increased with the addition of $\mathrm{BC}$ or MBC, the control with higher As(III) and As(V) concentration strongly affected grain amino acid status, resulting in modification and degradation of protein, and subsequently leading to inhibition of amino acid synthesis (Davies et al., 1987). Some findings indicate that organic As species, i.e. DMAA has a high capacity to bind protein in rice grain. MBC amendment showed less As accumulation in brown rice and responded to detoxification of As through preventing its entry into the grain. Therefore, MBC amended to As-contaminated soil may have a positive effect on amino acid and protein metabolism thus further improving rice plants growth.

\subsection{Arsenic concentrations and species in soil and Fe/Mn oxide membrane content}


Inorganic As was the predominant arsenic species in the soil, accounting for almost $100 \%$ of arsenic, of which As(V) accounted for more than $85 \%$ (Fig. 3). The available As species and concentrations were influenced by the amendment of MBC to the contaminated soils. Incorporation of $\mathrm{BC}$ and $\mathrm{MBC}$ decreased $\mathrm{As}(\mathrm{III})$ and $\mathrm{As}(\mathrm{V})$ mobility and availability, with As(III) concentration decreasing from 54.0 to $81.6 \%$, and $\mathrm{As}(\mathrm{V})$ concentration from 11.7 to $28.5 \%$ compared with the control in both soils. The lowest concentrations of As(III) and As(V) were recorded in heavily As-contaminated soil amended with 2\% $\mathrm{MBC}$ and in moderately As-contaminated soil amended with $1 \%$ MBC. As concentration in soils amended with $1 \%$ or $2 \% \mathrm{MBC}$ was lower than the maximum allowable concentration $\left(30 \mathrm{mg} \mathrm{g}^{-1}\right.$ for soil with $\mathrm{pH}<6.5 ; 25 \mathrm{mg} \mathrm{g}^{-1}$ for soil with $\mathrm{pH}$ 6.5-7.5) for agricultural soil according to the Chinese Environmental Quality Standard for Soils (Chinese Environmental Protection Agency, 1995). In the soil environment, As exists primarily in the form of water-soluble, exchangeable, and stable arsenic. As speciation is closely related to soil $\mathrm{pH}$. Hence, the role of $\mathrm{pH}$ in relation to As adsorption is important, especially on iron-oxide surfaces, where alkaline $\mathrm{pH}$ can favour solubility and ability of $\mathrm{As}(\mathrm{V})$ and sometimes $\mathrm{As}$ (III) (Jain et al., 1999). In the heavily-contaminated soil, the addition of MBC reduced the soil $\mathrm{pH}$ from 7.21 to 6.95 , compared with the $\mathrm{BC}$ treatments. In the moderately contaminated soil, the amendment of MBC did not reduce soil $\mathrm{pH}$ (Table 6).

The Fe and Mn levels in the iron-manganese plaque that was formed on the rice root surface differed among the treatments (Fig. 4). The Fe content on the root surface, ranging from 11.0 to $18.0 \mathrm{~g} \mathrm{~kg}^{-1}$, was considerably greater than Mn content, ranging from 0.004 to 3.7 $\mathrm{g} \mathrm{kg}^{-1}$. Treatment with $\mathrm{BC}$ and $\mathrm{MBC}$ amendment showed no significant difference in $\mathrm{Fe}$ content $(p>0.05)$. However, MBC addition significantly enhanced Mn content $(p<0.05)$. Thus, application of $2 \% \mathrm{MBC}$ increased $\mathrm{Mn}$ content in heavily As-contaminated and moderately As-contaminated soils by 36- and 10-folds respectively, compared to the control.

It is known that $\mathrm{Fe} / \mathrm{Mn}$ plaque has the stronger affinity to arsenate than arsenite. Hansel et al. (2002) showed that As(V) and As(III) co-exist in Fe/Mn plaques on the root surface of two common aquatic plant species; they comprised predominantly $\mathrm{As}(\mathrm{V})(82 \%)$, while the rest (18\%) consisted of As(III)-Fe (hydro-) oxide complexes, although the predominant species of As in flooded soil was As(III).

$\mathrm{As}(\mathrm{III})$ and $\mathrm{As}(\mathrm{V})$ in soil form surface complexes with a number of different oxides, especially $\mathrm{Fe}, \mathrm{Mn}$, and $\mathrm{Al}$ oxides, resulting in decreased mobility and bioavailability. Manganese oxides are strong oxidants that can oxidize and sequester many trace metals found in nature (Toner et al., 2006; Young and Harvey, 1992). Figures 1 and 2 show the impact of Mn oxide-modified biochar amendment on As concentration in grain. For both types of soil amended with $1 \%$ and $2 \% \mathrm{MBC}$, the overall As concentration in the grain showed a decreasing trend with the increased MBC rate. Amending $2 \% \mathrm{MBC}$ to both heavily and moderately As-contaminated soils reduced As concentrations in the grain by 13.9 - 
19.8\%. Therefore, Mn oxide amendment complemented biochar in reducing accumulation of As in grain. Moreover, since Mn oxide-modified biochar manufacture is economically available and practical in many areas of China, application of MBC to As-contaminated field can be implemented to reduce As accumulation in rice grain.

\section{Conclusions}

MBC and $\mathrm{BC}$ treatments had a substantial effect on the biomass and grain of rice, whereas the leaf, stem and root weight of some MBC or BC amended treatments were only slightly higher than those observed in the control groups in both heavily and moderately Ascontaminated soils. MBC application to paddy soils resulted in a greater decrease of As concentrations than $\mathrm{BC}$ treatments in rice grain and root. As(III) was the most prominent arsenic species in most parts of rice in both As-contaminated soils; it contributed to approximately $80 \%$ of the As in the grain of rice and more than $50 \%$ in the leaves and stems. MBC amendment detoxified As through preventing its entry into the grain, which positively affected amino acid and protein metabolism and further improved rice plants growth. Therefore, MBC application at an adequate rate in paddy fields to control arsenic uptake is an effective method to reduce As accumulation in rice plants that grow in South China.

\section{Acknowledgment}

The authors are grateful for financial support from the National Science Foundation of China (41273136).

\section{Reference}

Abedin, M. J., Feldmann, J., Meharg, A. A., 2002. Uptake kinetics of arsenic species in rice plants. Plant Physiol. 128, 1120-1128.

Ahmad, M., Rajapaksha, A.U., Lim, J.E., Zhang, M., Bolan, N., Mohan, D., Vithanage, M., Lee, S.S., Ok, Y.S., 2014. Biochar as a sorbent for contaminant management in soil and water: a review. Chemosphere 99, 19-33.

Balasubramanian, N., Kojima, T., Basha, C. A., Srinivasakannan, C., 2009. Removal of arsenic from aqueous solution using electrocoagulation. J. Hazard. mater. 167(1), 966-969. Beesley, L., Moreno-Jiménez, E., Gomez-Eyles, J. L., Harris, E., Robinson, B., Sizmur, T., 2011. A review of biochars' potential role in the remediation, revegetation and restoration of contaminated soils. Environ. Pollut. 159(12), 3269-3282.

Cao, X.D., Ma, L.Q., 2004. Effects of compost and phosphate on plant arsenic accumulation from soils near pressure-treated wood. Environ. Pollut. 132,435-442.

Davies, K. J., 1987. Protein damage and degradation by oxygen radicals. I. general aspects. J. Biol. Chem. 262(20), 9895-9901. 
Dos Santos Costa, B. E., Coelho, N. M. M., Coelho, L. M., 2015. Determination of arsenic species in rice samples using CPE and ETAAS. Food. Chem. 178, 89-95.

Giordano, M., Castellino, P., 1997. Correlation between amino acid induced changes in energy expenditure and protein metabolism in humans. Nutrition.13(4), 309-312.

Gregory, S. J., Anderson, C. W. N., Arbestain, M. C., McManus, M. T., 2014. Response of plant and soil microbes to biochar amendment of an arsenic-contaminated soil. Agr. Ecosyst. Environ. 191, 133-141.

Gulz, P. A., Gupta, S. K., Schulin, R., 2005. Arsenic accumulation of common plants from contaminated soils. Plant. Soil. 272(1-2), 337-347.

Hansel, C. M., La Force, M. J., Fendorf, S., Sutton, S., 2002. Spatial and temporal association of As and Fe species on aquatic plant roots. Environ. Sci.Technol. 36(9), 1988-1994.

Hartley, W., Dickinson, N. M., Riby, P., Lepp, N. W., 2009. Arsenic mobility in brownfield soils amended with green waste compost or biochar and planted with Miscanthus. Environ. Pollut. 157(10), 2654-2662.

Hassan, A. F., Abdel-Mohsen, A. M., Elhadidy, H., 2014. Adsorption of arsenic by activated carbon, calcium alginate and their composite beads. Int. J. Biol. Macromol. 68, 125-130.

Heikens, A., 2006. Arsenic Contamination of Irrigation Water, Soil and Crops in Bangladesh: Risk Implications for Sustainable Agriculture and Food Safety in Asia. Food and Agricultural Organization of the United Nations, Regional Office for Asia and the Pacific.

Jain A., Raven K. P., Loeppert R. H., 1999. Arsenite and arsenate adsorption on ferrihydrite: surface charge reduction and net $\mathrm{OH}^{-}$release stoichiometry. Environ. Sci. Technol. 33,11791184.

Kabata-Pendias, A., Mukherjee, A. B., 2007. Trace elements from soil to human. Springer Science \& Business Media.

Komárek, M., Vaněk, A., Ettler, V., 2013. Chemical stabilization of metals and arsenic in contaminated soils using oxides-a review. Environ. Pollut. 172, 9-22.

Kumpiene, J., Lagerkvist, A., Maurice, C., 2008. Stabilization of $\mathrm{As}, \mathrm{Cr}, \mathrm{Cu}, \mathrm{Pb}$ and $\mathrm{Zn}$ in soil using amendments-a review. Waste. Manage. 28(1), 215-225.

Lafferty, B.J., Ginder-Vogel, M., Sparks, D.L., 2010. Arsenite oxidation by a poorly crystalline manganese-oxide I. Stirred-flow experiments. Environ. Sci. Technol. 44, 84608466.

Leupin, O. X., Hug, S. J., 2005. Oxidation and removal of arsenic (III) from aerated groundwater by filtration through sand and zero-valent iron. Water. Res.39(9), 1729-1740.

Liu, W. J., Zhu, Y. G., Smith, F. A., 2005. Effects of iron and manganese plaques on arsenic uptake by rice seedlings (Oryza sativa L.) grown in solution culture supplied with arsenate and arsenite. Plant. Soil. 277(1-2), 127-138.

Lou, C., Liu, W., Liu, X., 2014. Quantitative analysis of arsenic speciation in guano and ornithogenic sediments using microwave-assisted extraction followed by high-performance 
liquid chromatography coupled to hydride generation atomic fluorescence spectrometry. J.

Chromatogr B. 969, 29-34.

Marin, A.R., Masscheleyn, P.H., Patrick,W. H., 1992. The influence of chemical form and concentration of arsenic on rice growth and tissue arsenic concentration. Plant. Soil. 139,175183

Marques, A. P., Rangel, A. O., Castro, P. M., 2009. Remediation of heavy metal contaminated soils: phytoremediation as a potentially promising clean-up technology. Cri. Rev. Environ. Sci.Technol. 39(8), 622-654.

Meharg, A.A., Hartley-Whitaker, J., 2002. Arsenic uptake and metabolism in arsenic resistant and nonresistant plant species. New Phytologist. 154, 29-43.

Mench, M., Bussiere, S., Boisson, J., Castaing, E., Vangronsveld, J., Ruttens, A., Manceau, A.,2003. Progress in remediation and revegetation of the barren Jales gold mine spoil after in situ treatments. Plant. Soil. 249(1), 187-202.

Mohan, D., Sarswat, A., Ok, Y.S., Pittman, Jr. C.U., 2014. Organic and inorganic contaminants removal from water with biochar, a renewable, low cost and sustainable adsorbent. Bioresour Technology. 160, 191-202.

Naidu, R., Smith, E., Owens, G., Bhattacharya, P., Nadebaum, P., 2006. Managing arsenic in the environment - from soil to human. CSIRO Publishing, Melbourne,Australia.

Namgay, T., Singh B., Singh, B., P., 2010. Plant availability of arsenic and cadmium as influenced by biochar application to soil. In 19th World Congress of Soil Science.

Neidhardt, H., Norra, S., Tang, X., Guo, H., Stüben, D., 2012. Impact of irrigation with high arsenic burdened groundwater on the soil-plant system: results from a case study in the Inner Mongolia, China. Environ. Pollut. 63, 8-13.

Norton, G. J., Duan, G., Dasgupta, T., Islam, M. R., Lei, M., Zhu, Y., Meharg, A. A., 2009.

Environmental and genetic control of arsenic accumulation and speciation in rice grain: comparing a range of common cultivars grown in contaminated sites across Bangladesh, China, and India. Environ. Sci.Technol. 43(21), 8381-8386.

Novak, J. M., Busscher, W. J., Laird, D. L., Ahmedna, M., Watts, D. W., Niandou, M. A., 2009. Impact of biochar amendment on fertility of a southeastern coastal plain soil. Soil Sci. 174(2), 105-112.

Otte, M. L., Dekkers, I. M. J., Rozema, J., Broekman, R. A., 1991. Uptake of arsenic by Aster tripolium in relation to rhizosphere oxidation. Can. J. Bot. 69(12), 2670-2677.

Rosas-Castor, J. M., Guzmán-Mar, J. L., Alfaro-Barbosa, J. M., Hernández-Ramírez, A., Pérez-Maldonado, I. N., Caballero-Quintero, A., Hinojosa-Reyes, L., 2014. Evaluation of the transfer of soil arsenic to maize crops in suburban areas of San Luis Potosi, Mexico. Sci. Total Environ. 497, 153-162.

Smith, E., Naidu, R., Alston, A.M., 1998. Arsenic in the soil environment: a review. Advances in Agronomy. 64, 149-195. 
Taylor, G. J., Crowder, A. A., 1983. Use of the DCB technique for extraction of hydrous iron oxides from roots of wetland plants. Am. J. Bot.70(8),1254-1257.

Toner, B., Manceau, A., Webb, S. M., Sposito, G., 2006. Zinc sorption to biogenic hexagonalbirnessite particles within a hydrated bacterial biofilm. Geochim. Cosmochim. Ac. 70(1), $27-$ 43.

Uchimiya, M., Wartelle, L. H., Klasson, K. T., Fortier, C. A., Lima, I. M., 2011. Influence of pyrolysis temperature on biochar property and function as a heavy metal sorbent in soil. J. Agric. Food. Chem. 59(6), 2501-2510.

Warren, G.P., Alloway, B.J., Lepp, N.W., Singh, B., Bochereau, F.J.M., Penny, C., 2003. Field trials to assess the uptake of arsenic by vegetables from contaminated soils and soil remediation with iron oxides. Sci. Total Environ. 311, 19-33.

Williams, P.N., Villada, A., Deacon, C., Raab, A., Figuerola, J., Green, A.J., Meharg, A.A., 2007. Greatly enhanced arsenic shoot assimilation in rice leads to elevated grain concentrations compared to wheat and barley. Environ. Sci.Technol. 41, 6854-6859.

Young, L. B., Harvey, H. H., 1992. The relative importance of manganese and iron oxides and organic matter in the sorption of trace metals by surficial lake sediments. Geochim. Cosmochim. Ac. 56(3), 1175-1186.

Yu, Z.H., Zhou, L., Huang, Y. F., Song, Z.G., Qiu, W.W., 2015. Effects of a manganese oxidemodified biochar composite on adsorption of arsenic in red soil. J. Environ. Manage. 163, 155-162.

Yuan,C. G., He,B., Gao, E. L., Lv, J. X., Jiang G. B., 2007.Evaluation of extraction methods for arsenic speciation in polluted soil and rotten ore by HPLC-HG-AFS analysis. Microchim. Acta. 159 (1-2), 175-182.

Zhu, Y. G., Sun, G. X., Lei, M., Teng, M., Liu, Y. X., Chen, N. C., Wang, L.H., Carey, A.M., Deacon, C., Raab, A., Meharg, A.A.,Williams, P. N., 2008. High percentage inorganic arsenic content of mining impacted and nonimpacted Chinese rice. Environ. Sci.Technol. 42(13), 5008-5013.

Zimmerman, A.R., Gao, M., Ahn M.Y., 2011. Positive and negative carbon mineralization priming effects among a variety of biochar-amended soils. Soil Bio. Biogeochem. 43,11691179. 
Figure

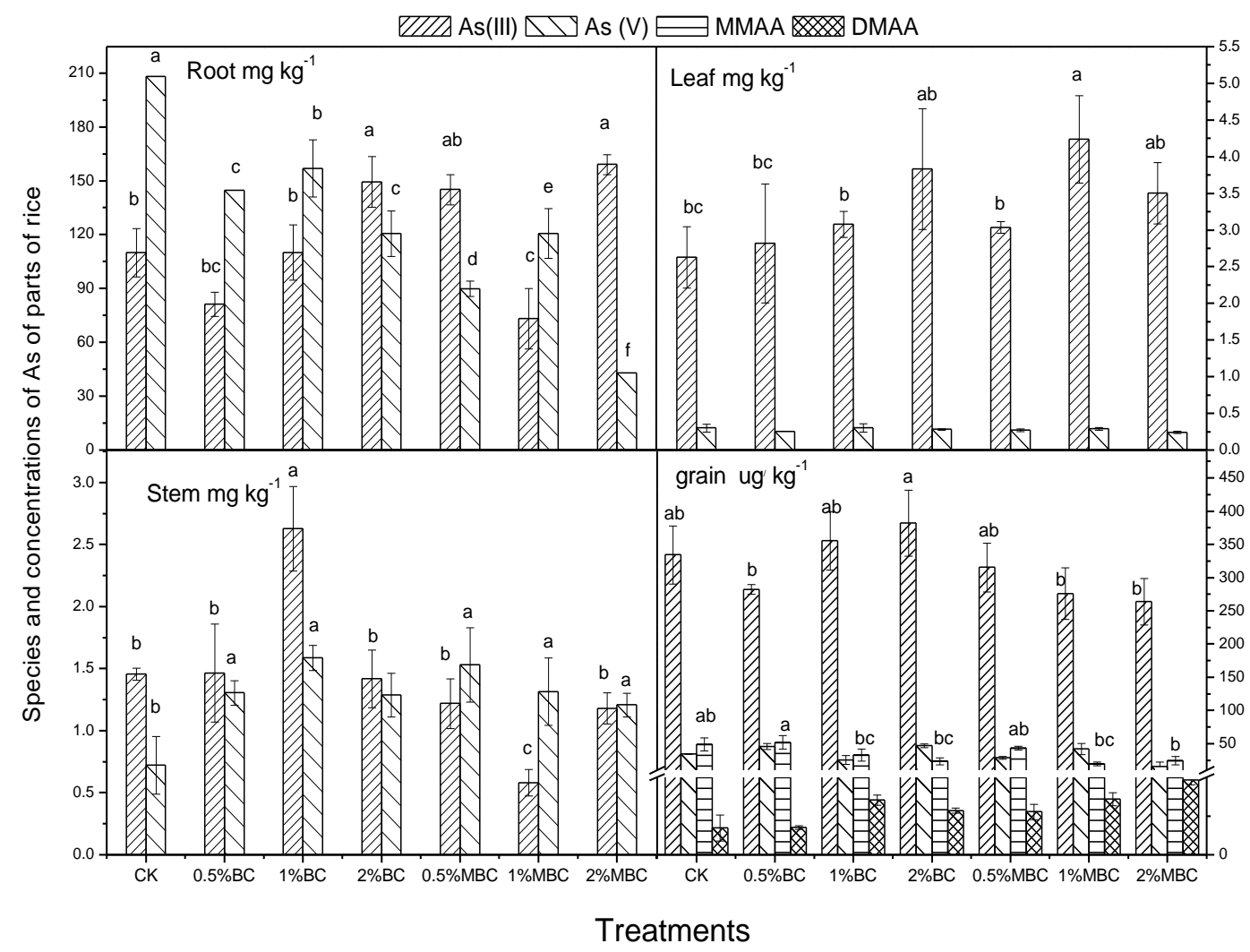

Fig. 1 Arsenic speciation and concentrations in each part of rice in heavily Ascontaminated soil (Data are mean \pm standard error of the mean $(n=3)$. The same letter means no significant differences in figure $(p<0.05))$. 


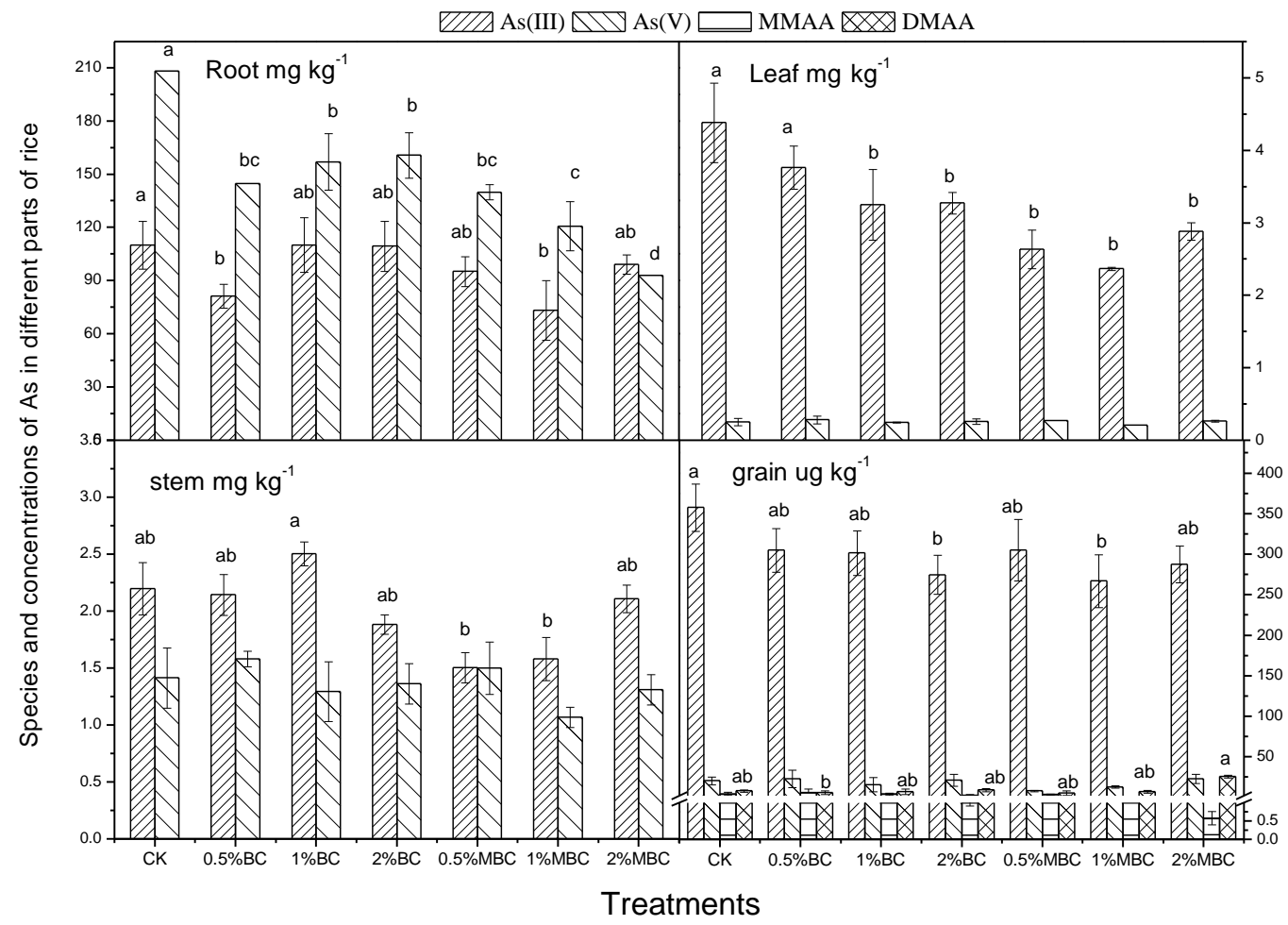

Fig. 2 Arsenic speciation and concentrations in each part of rice in moderately Ascontaminated soil (Data are mean \pm standard error of the mean $(n=3)$. The same letter means no significant differences in figure $(p<0.05)$ ). 


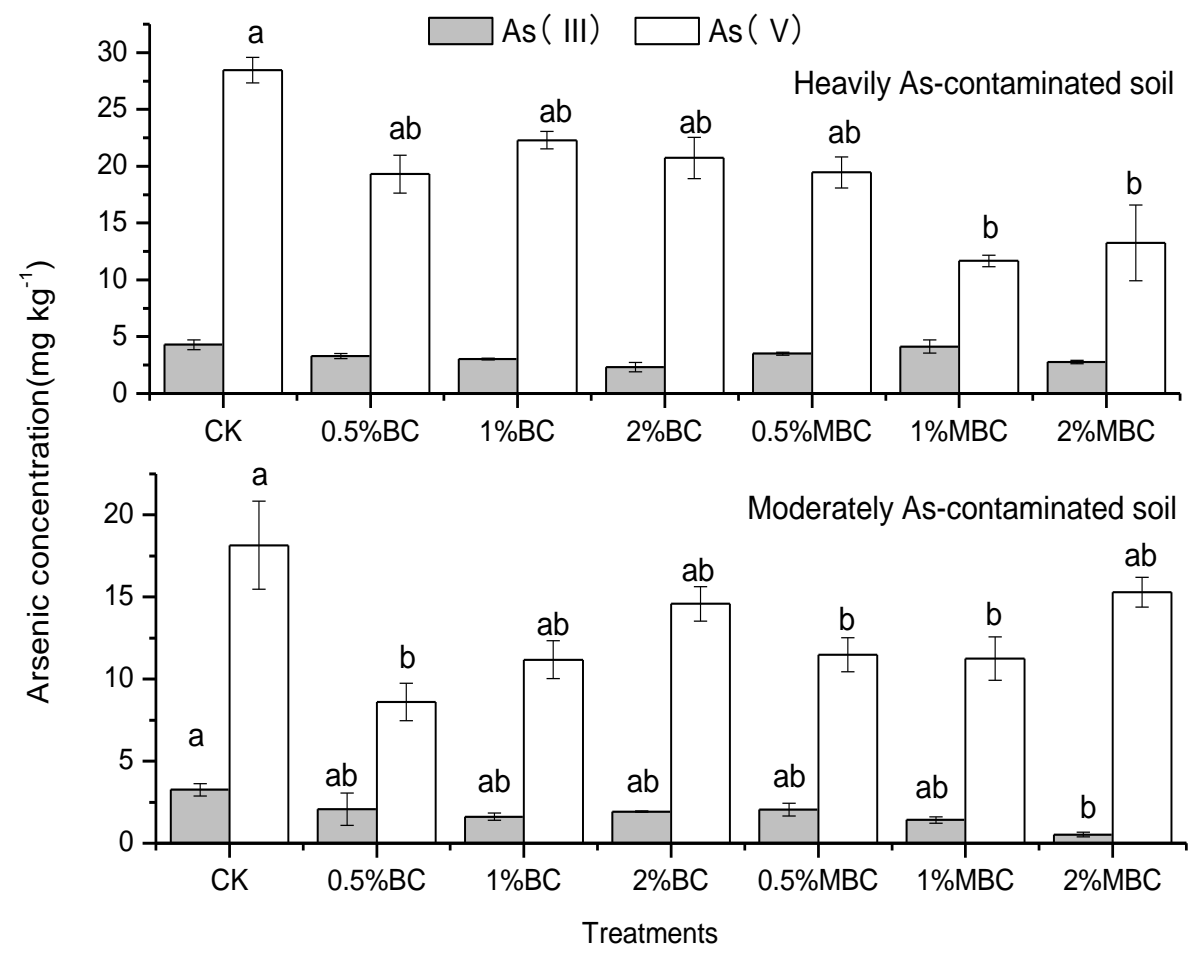

Fig. 3 Extraction As concentration from soil after adding different rates $\mathrm{MBC}$ and $\mathrm{BC}$ (Data are mean \pm standard error of the mean $(n=3)$. The same letter means no significant differences in figure $(p<0.05))$. 


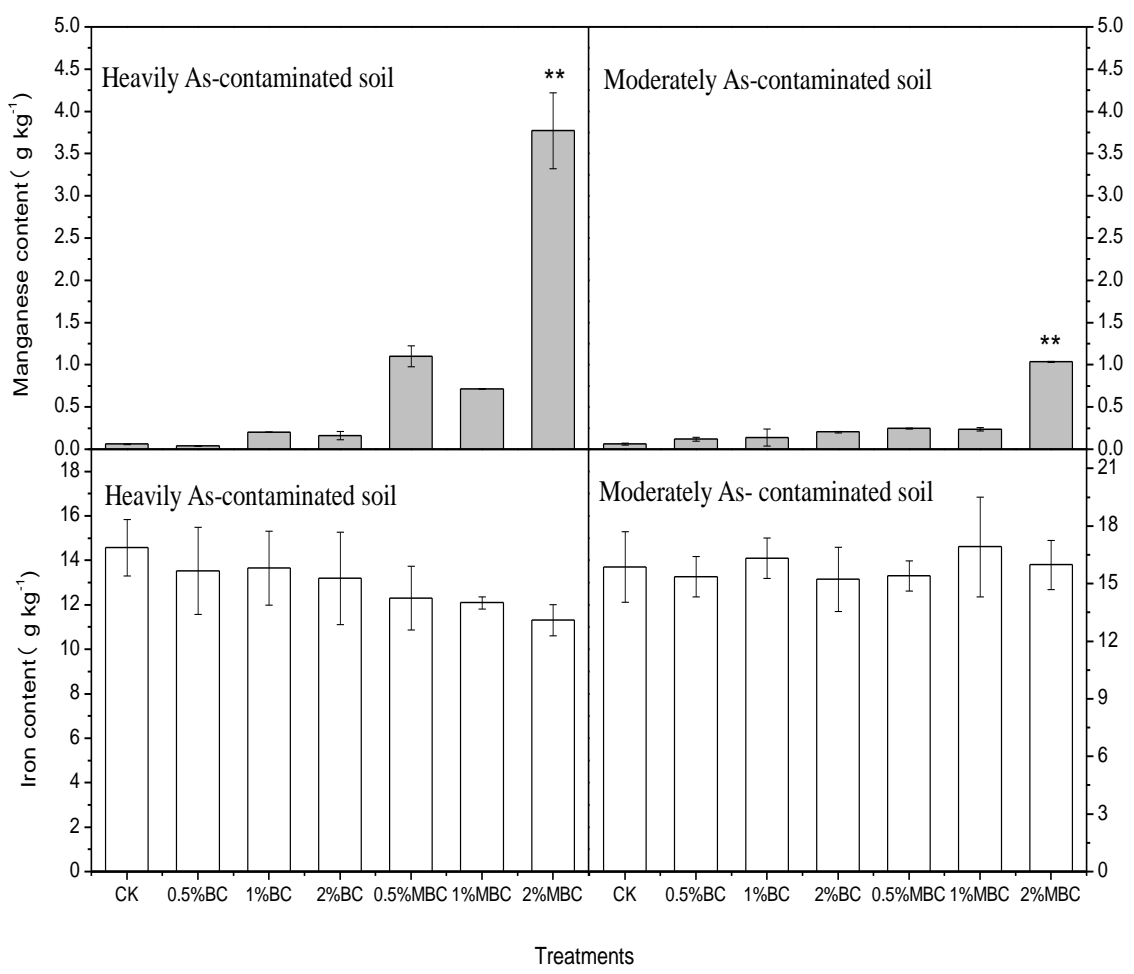

Fig. 4 The content of $\mathrm{Fe}$ and $\mathrm{Mn}$ in iron-manganese plaque of rice root (Data are mean \pm standard error of the mean $(n=3)$. The asterisk means significant differences in figure $(p<0.05))$. 
Table

Table 1 Physical and chemical properties of As-contaminated soils

\begin{tabular}{lrrrrrr}
\hline \multirow{2}{*}{ Soils } & Arsenic & Iron oxides & Available P & Organic matter & Clay & pH \\
\cline { 2 - 5 } & & & $\mathrm{mg} \mathrm{kg}^{-1}$ & $\mathrm{~g} \mathrm{~kg}^{-1}$ & $\%$ & \\
\hline Heavily As- contaminated & 73.0 & 5.62 & 8.30 & 43.8 & 47.4 & 7.21 \\
Moderately As- contaminated & 47.2 & 5.49 & 5.61 & 43.6 & 46.8 & 7.08 \\
\hline
\end{tabular}


Table 2 Physical and chemical characteristics of biochar and manganese oxide-biochar composite

\begin{tabular}{|c|c|c|c|c|c|c|c|c|c|}
\hline \multirow[t]{2}{*}{ Amendment } & Ash & $\begin{array}{l}\text { Volatile } \\
\text { Matter }\end{array}$ & $\mathrm{Mn}$ & $\mathrm{N}$ & $\mathrm{C}$ & $\mathrm{O}$ & $\mathrm{H}$ & \multirow[t]{2}{*}{$\mathrm{pH}$} & $\mathrm{S}_{\mathrm{BET}}$ \\
\hline & & & & $\%$ & & & & & $\left(\mathrm{~m}^{2} \mathrm{~g}^{-1}\right)$ \\
\hline $\mathrm{BC}$ & 10.2 & 9.32 & $\mathrm{nd}^{*}$ & 0.80 & 85.3 & 5.16 & 1.75 & 10.4 & 60.9 \\
\hline MBC & 12.6 & 9.76 & 7.41 & 0.72 & 73.0 & 10.9 & 0.33 & 10.8 & 3.18 \\
\hline
\end{tabular}

Note: $\mathrm{S}_{\mathrm{BET}}$ means specific surface area by BET analyzed. nd means not detected (The detection limits of atomic adsorption spectrometry were about $0.08 \mathrm{mg} \mathrm{L}^{-1} \mathrm{Mn}$ ). 
Table 3 Effects of different rates of MBC amendment on the biomass of rice grown in different level arsenic contaminated soils $\left(\mathrm{g} \mathrm{pot}^{-1}\right)$

\begin{tabular}{cllllll}
\hline & Treatments & Root & Stem & Leaf & Grain & Biomass \\
\hline & Control & $2.65 \pm 0.47 \mathrm{~b}$ & $2.54 \pm 0.40 \mathrm{c}$ & $4.18 \pm 0.25 \mathrm{~d}$ & $8.42 \pm 0.54 \mathrm{~d}$ & $17.8 \pm 0.62 \mathrm{c}$ \\
Heavily As- & $1 \% \mathrm{BC}$ & $3.58 \pm 0.31 \mathrm{a}$ & $3.31 \pm 0.10 \mathrm{~b}$ & $7.13 \pm 0.17 \mathrm{a}$ & $11.5 \pm 0.72 \mathrm{c}$ & $25.5 \pm 0.61 \mathrm{~b}$ \\
contaminated soil & $2 \% \mathrm{BC}$ & $3.45 \pm 0.39 \mathrm{a}$ & $3.58 \pm 0.44 \mathrm{~b}$ & $6.34 \pm 0.42 \mathrm{ab}$ & $12.9 \pm 0.56 \mathrm{bc}$ & $26.3 \pm 0.48 \mathrm{~b}$ \\
& $0.5 \% \mathrm{MBC}$ & $3.10 \pm 0.55 \mathrm{ab}$ & $2.86 \pm 0.21 \mathrm{bc}$ & $5.80 \pm 0.17 \mathrm{~b}$ & $13.6 \pm 0.61 \mathrm{~b}$ & $25.3 \pm 0.53 \mathrm{~b}$ \\
& $1 \% \mathrm{MBC}$ & $3.52 \pm 0.23 \mathrm{a}$ & $3.70 \pm 0.19 \mathrm{a}$ & $6.50 \pm 0.38 \mathrm{ab}$ & $14.4 \pm 0.84 \mathrm{ab}$ & $28.1 \pm 0.65 \mathrm{a}$ \\
& $2 \% \mathrm{MBC}$ & $3.47 \pm 0.15 \mathrm{a}$ & $3.69 \pm 0.37 \mathrm{a}$ & $5.14 \pm 0.86 \mathrm{bc}$ & $15.7 \pm 0.24 \mathrm{a}$ & $28.0 \pm 0.22 \mathrm{ab}$ \\
\cline { 2 - 5 } & Control & $2.84 \pm 0.17 \mathrm{~b}$ & $3.43 \pm 0.48 \mathrm{c}$ & $9.05 \pm 0.44 \mathrm{ab}$ & $18.2 \pm 0.38 \mathrm{~b}$ & $33.5 \pm 0.48 \mathrm{c}$ \\
& $0.5 \% \mathrm{BC}$ & $3.34 \pm 0.32 \mathrm{a}$ & $3.98 \pm 0.41 \mathrm{ab}$ & $9.27 \pm 1.01 \mathrm{ab}$ & $19.6 \pm 0.96 \mathrm{ab}$ & $36.2 \pm 82 \mathrm{ab}$ \\
Moderately As- & $1 \% \mathrm{BC}$ & $2.52 \pm 0.07 \mathrm{bc}$ & $3.04 \pm 0.62 \mathrm{~d}$ & $10.0 \pm 0.96 \mathrm{a}$ & $19.9 \pm 0.33 \mathrm{ab}$ & $35.5 \pm 0.33 \mathrm{~b}$ \\
& $2 \% \mathrm{BC}$ & $2.53 \pm 0.20 \mathrm{bc}$ & $4.15 \pm 0.24 \mathrm{ab}$ & $8.76 \pm 0.50 \mathrm{ab}$ & $17.6 \pm 0.24 \mathrm{~b}$ & $33.1 \pm 0.56 \mathrm{c}$ \\
& $0.5 \% \mathrm{MBC}$ & $2.97 \pm 0.31 \mathrm{bc}$ & $3.88 \pm 0.23 \mathrm{a}$ & $9.44 \pm 0.15 \mathrm{ab}$ & $21.8 \pm 0.49 \mathrm{a}$ & $38.1 \pm 0.54 \mathrm{a}$ \\
& $1 \% \mathrm{MBC}$ & $3.01 \pm 0.28 \mathrm{bc}$ & $3.85 \pm 0.28 \mathrm{~b}$ & $9.11 \pm 0.21 \mathrm{~b}$ & $21.5 \pm 0.47 \mathrm{a}$ & $37.5 \pm 0.58 \mathrm{ab}$
\end{tabular}

Note: the same letter means no significant differences in half column $(p<0.05)$. 
Table 4 Total arsenic concentrations in each parts of rice grown in different level arsenic contaminated soils $\left(\mathrm{mg} \mathrm{kg}^{-1}\right)$

\begin{tabular}{llllll}
\hline & Treatments & Root & Stem & Leaf & Grain \\
\hline & Control & $356 \pm 23.4 \mathrm{a}$ & $3.93 \pm 0.12 \mathrm{a}$ & $4.88 \pm 0.22 \mathrm{a}$ & $0.349 \pm 0.02 \mathrm{~b}$ \\
Heavily As- & $0.5 \% \mathrm{BC}$ & $241 \pm 10.3 \mathrm{ab}$ & $3.08 \pm 0.52 \mathrm{~b}$ & $3.77 \pm 0.39 \mathrm{~b}$ & $0.328 \pm 0.01 \mathrm{bc}$ \\
contaminated soil & $1 \% \mathrm{BC}$ & $244 \pm 5.34 \mathrm{ab}$ & $3.38 \pm 0.18 \mathrm{~b}$ & $3.72 \pm 0.34 \mathrm{~b}$ & $0.371 \pm 0.03 \mathrm{ab}$ \\
& $2 \% \mathrm{BC}$ & $214 \pm 7.30 \mathrm{ab}$ & $4.12 \pm 0.82 \mathrm{ab}$ & $3.71 \pm 0.82 \mathrm{~b}$ & $0.409 \pm 0.03 \mathrm{a}$ \\
& $0.5 \% \mathrm{MBC}$ & $208 \pm 7.01 \mathrm{ab}$ & $3.31 \pm 0.08 \mathrm{~b}$ & $2.75 \pm 0.20 \mathrm{c}$ & $0.345 \pm 0.04 \mathrm{~b}$ \\
& $1 \% \mathrm{MBC}$ & $131 \pm 4.13 \mathrm{~b}$ & $3.53 \pm 0.20 \mathrm{~b}$ & $2.50 \pm 0.11 \mathrm{~d}$ & $0.308 \pm 0.02 \mathrm{bc}$ \\
& $2 \% \mathrm{MBC}$ & $123 \pm 3.83 \mathrm{~b}$ & $3.75 \pm 0.42 \mathrm{ab}$ & $2.69 \pm 0.13 \mathrm{c}$ & $0.280 \pm 0.04 \mathrm{c}$ \\
\hline & Control & $328 \pm 13.8 \mathrm{a}$ & $3.91 \pm 0.23 \mathrm{a}$ & $4.64 \pm 0.55 \mathrm{a}$ & $0.338 \pm 0.039 \mathrm{a}$ \\
As-contaminated soil & $0.5 \% \mathrm{BC}$ & $246 \pm 10.8 \mathrm{~cd}$ & $3.42 \pm 0.19 \mathrm{a}$ & $4.05 \pm 0.29 \mathrm{ab}$ & $0.328 \pm 0.026 \mathrm{ab}$ \\
& $1 \% \mathrm{BC}$ & $267 \pm 15.8 \mathrm{~b}$ & $3.10 \pm 0.11 \mathrm{a}$ & $3.50 \pm 0.48 \mathrm{~b}$ & $0.317 \pm 0.024 \mathrm{ab}$ \\
& $2 \% \mathrm{BC}$ & $270 \pm 14.1 \mathrm{~b}$ & $3.25 \pm 0.08 \mathrm{ab}$ & $3.53 \pm 0.14 \mathrm{~b}$ & $0.296 \pm 0.021 \mathrm{~b}$ \\
& $0.5 \% \mathrm{MBC}$ & $235 \pm 8.48 \mathrm{c}$ & $3.00 \pm 0.13 \mathrm{ab}$ & $2.91 \pm 0.56 \mathrm{~b}$ & $0.313 \pm 0.038 \mathrm{ab}$ \\
& $1 \% \mathrm{MBC}$ & $194 \pm 16.7 \mathrm{de}$ & $2.65 \pm 0.49 \mathrm{~b}$ & $2.58 \pm 0.02 \mathrm{~b}$ & $0.278 \pm 0.042 \mathrm{~b}$
\end{tabular}

Note: the same letter means no significant differences in half column $(p<0.05)$. 
Table 5 The content of amino acid in rice grains in different level arsenic contaminated soils

\begin{tabular}{|c|c|c|c|c|c|}
\hline & \multirow{2}{*}{ Treatments } & $\begin{array}{c}\text { Essential } \\
\text { amino acids }\end{array}$ & $\begin{array}{l}\text { Non-essential } \\
\text { amino acids }\end{array}$ & $\begin{array}{l}\text { Total amino } \\
\text { acids }\end{array}$ & $\begin{array}{l}\text { Ratio of essential amino } \\
\text { acids / total amino acids }\end{array}$ \\
\hline & & \multicolumn{4}{|c|}{$\%$} \\
\hline \multirow{7}{*}{$\begin{array}{l}\text { Heavily As- } \\
\text { contaminated soil }\end{array}$} & Control & $3.63 \pm 0.48$ & $7.24 \pm 0.25$ & $10.8 \pm 0.73$ & 34.1 \\
\hline & $0.5 \% \mathrm{BC}$ & $3.49 \pm 0.28$ & $6.29 \pm 0.16$ & $9.79 \pm 0.44$ & 34.3 \\
\hline & $1 \% \mathrm{BC}$ & $3.49 \pm 0.26$ & $6.86 \pm 0.12$ & $10.3 \pm 0.38$ & 34.6 \\
\hline & $2 \% \mathrm{BC}$ & $3.33 \pm 0.60$ & $6.84 \pm 0.31$ & $10.1 \pm 0.92$ & 34.0 \\
\hline & $0.5 \% \mathrm{MBC}$ & $3.75 \pm 0.44$ & $7.44 \pm 0.26$ & $11.2 \pm 0.70$ & 34.4 \\
\hline & $1 \% \mathrm{MBC}$ & $3.35 \pm 0.50$ & $6.64 \pm 0.33$ & $9.99 \pm 0.84$ & 34.7 \\
\hline & $2 \% \mathrm{MBC}$ & $3.70 \pm 0.77$ & $7.34 \pm 0.33$ & $11.0 \pm 1.0$ & 34.7 \\
\hline \multirow{7}{*}{$\begin{array}{l}\text { Moderately As- } \\
\text { contaminated soil }\end{array}$} & Control & $3.28 \pm 0.15$ & $6.24 \pm 0.30$ & $9.52 \pm 0.28$ & 34.4 \\
\hline & $0.5 \% \mathrm{BC}$ & $3.47 \pm 0.24$ & $6.40 \pm 0.38$ & $9.88 \pm 0.63$ & 35.1 \\
\hline & $1 \% \mathrm{BC}$ & $3.55 \pm 0.34$ & $6.53 \pm 0.50$ & $10.1 \pm 0.85$ & 35.2 \\
\hline & $2 \% \mathrm{BC}$ & $3.57 \pm 0.34$ & $6.69 \pm 1.84$ & $10.26 \pm 2.79$ & 34.8 \\
\hline & $0.5 \% \mathrm{M}$ & $3.35 \pm 0.04$ & $5.88 \pm 0.30$ & $9.23 \pm 0.35$ & 36.3 \\
\hline & $1 \% \mathrm{MB}$ & $3.24 \pm 0.23$ & $5.78 \pm 0.57$ & $9.03 \pm 0.81$ & 35.9 \\
\hline & $2 \% \mathrm{MB}$ & $3.59 \pm 0.10$ & $5.98 \pm 0.95$ & $9.57 \pm 1.15$ & 37.5 \\
\hline
\end{tabular}


Table 6 Soil pH change after adding different rates of biochars and manganese oxide-modified biochar

\begin{tabular}{lcc}
\hline Treatments & Heavily As-contaminated soil & Moderately As-contaminated soil \\
\hline Control & 7.21 & 7.08 \\
$0.5 \% \mathrm{BC}$ & 7.37 & 7.22 \\
$1 \% \mathrm{BC}$ & 6.99 & 7.51 \\
$2 \% \mathrm{BC}$ & 7.24 & 7.51 \\
$0.5 \% \mathrm{MBC}$ & 7.02 & 7.17 \\
$1 \% \mathrm{MBC}$ & 6.98 & 7.44 \\
$2 \% \mathrm{MBC}$ & 6.95 & 7.46 \\
\hline
\end{tabular}

